\title{
EXPERIMENTAL MENINGOENCEPHALOMYELITIS BY Encephalitozoon cuniculi IN CYCLOPHOSPHAMIDE-IMMUNOSUPPRESSED MICE
}

\author{
Maria Anete Lallo, Eduardo Fernandes Bondan
}

\begin{abstract}
Encephalitozoonosis is an increasingly important opportunistic protozoan infection in immunocompromised individuals. This study aims to examine the development of an experimental Encephalitozoon cuniculi infection in the central nervous system of immunosuppressed mice. Adult Balb-C mice were inoculated intraperitoneally with $E$. cuniculi spores, treated with cyclophosphamide during the experimental period and killed from 15 to 75 days post-inoculation. Tissue samples were collected and processed for light and transmission electron microscopy investigation. Multifocal granulomas were seen in all organs. A lymphocytic, diffuse, non-suppurative menigoencephalomyelitis was observed, with neuronal degeneration and necrosis, macrophagic infiltration and reactive astrocytosis. E. cuniculi spores were seen in the microgranulomas or occurred unassociated with inflammatory reaction. The parasites were rarely seen in Hematoxylin-Eosin stained sections, but were Gram-Chromotrope positive. Proliferative forms and spores were found in parasitophorous vacuoles within neural cells and macrophages. Experimental encephalitozoonosis in immunosuppressed mice provides an useful model for the study of brain lesions associated with these protozoans in man.
\end{abstract}

KEY WORDS: cyclophosphamide, Encephalitozoon cuniculi, experimental infection, imunosuppression, mice, meningoencephalomyelitis.

\begin{abstract}
Meningoencefalomielite experimental por Encephalitozoon cuniculi em camundongos imunossuprimidos com ciclofosfamida

RESUMO - A encefalitozoonose constitui protozoose emergente em indivíduos imunocomprometidos. Este estudo visa examinar o desenvolvimento de infecção experimental por Encephalitozoon cuniculi no sistema nervoso central de camundongos imunossuprimidos. Camundongos Balb-C adultos foram inoculados intraperitonealmente com esporos de $E$. cuniculi, tratados com ciclofosfamida durante o período experimental e sacrificados dos 15 aos 75 dias pós-inoculação. Fragmentos teciduais foram coletados e processados para estudos de microscopia de luz e eletrônica de transmissão. Granulomas multifocais foram vistos em todos os órgãos. Foi observada meningoencefalomielite linfocítica, difusa, não-supurativa, com degeneração e necrose neuronal, infiltração macrofágica e astrocitose reativa. Esporos de $E$. cuniculi foram vistos nos microgranulomas ou ocorreram sem associação com reação inflamatória. Os parasitas raramente foram notados em cortes corados com Hematoxilina-Eosina, mas eram Gram-chromotrope-positivos. Esporos e formas proliferativas foram encontrados em vacúolos parasitóforos dentro de células neurais e macrófagos. A encefalitozoonose experimental em camundongos imunossuprimidos fornece um modelo adequado para o estudo de lesões cerebrais associadas com tais protozoários no homem.
\end{abstract}

PALAVRAS-CHAVE: camundongos, ciclofosfamida, Encephalitozoon cuniculi, imunosupressão, infecção experimental, meningoencefalomielite.

Microsporidia are obligate intracellular protozoal parasites that infect a variety of cell types in a broad range of vertebrates and invertebrates ${ }^{1}$. Thirteen genera of microsporidia have been reported to infect humans ${ }^{2}$. Encephalitozoon cuniculi is by far the most common spontaneously occurring microsporidian parasite of animals $\mathrm{s}^{2,3}$, including a wide range of hosts, such as rodents, carnivores and primates ${ }^{2,3}$.
Experimental $E$. cuniculi infections in immunocompetent hosts usually produce only chronic asymptomatic brain and kidney lesions ${ }^{4,5}$. In contrast, the inoculation of immunodeficient animals, such as athymic mice, results in the lethal disease ${ }^{4-7}$.

As encephalitozoonosis is an increasingly important opportunistic protozoan infection in immunocompromised individuals, such as HIV-positive pa-

Veterinary Immunopathology Laboratory, Paulista University (UNIP), São Paulo SP, Brazil.

Received 9 August 2004, received in final form 25 October 2004. Accepted 4 December 2004.

Dr. Maria Anete Lallo - Rua Caconde 125 / 51 - 01425-011 São Paulo SP - Brasil. E-mail: bondan@uol.com.br 
tients ${ }^{6}$, this study aims to examine the development of an experimental E. cuniculi infection in the central nervous system (CNS) of mice immunosuppressed with cyclophosphamide (CY) as a suitable animal model to study the disease in humans.

\section{METHOD}

Adult Balb-C mice were divided into 4 groups - group I $(n=50)$, including immunosuppressed mice inoculated with E. cuniculi; group II $(n=50)$ - immunocompetent mice inoculated with E. cuniculi; group III $(n=10)$ - immunosuppressed, but non-infected, mice; group IV ( $n=5)$, non-infected and non-immunosuppressed animals taken as histologic controls. Mice from groups I and II were inoculated with $2 \times 10^{8} \mathrm{E}$. cuniculi spores by intraperitoneal route. These spores were grown in Madin Darby Canine Kidney (MDCK) cells and purified by centrifugation over $50 \%$ Percoll (Pharmacia) as described by Didier et al. ${ }^{8}$. Immunosuppression was induced by cyclophosphamide treatment $(50 \mathrm{mg} / \mathrm{kg}$, twice a week) by intraperitoneal route during the experimental period. The animals were killed at 15, 30, 45, 60 and 75 days post-inoculation and tissue samples, including brain, spinal cord, liver, kidneys, gut and lungs, were collected and processed for light and transmission electron microscopy investigation. Hematoxylin-Eosin (HE) and Gram-Chromotrope (according to Moura et al. ${ }^{9}$ ) staining techniques were performed, as well as immunohistochemical staining (avidinbiotin method) to Glial Fibrillary Acidic Protein (GFAP Rabbit anti-cow GFA, Code number Z0334, Dako, 1:1000) and Vimentin (VIM, Mouse anti-swine Vimentin, Code number M0725, Dako, 1:200).

For ultrastructural study, thin slices of the cerebrum, brainstem, cerebellum and spinal cord were collected, fixed in a mixture of $2 \%$ glutaraldehyde in $0.2 \mathrm{M}$ phosphate buffer $(\mathrm{pH} 7.2)$, post-fixed in $1 \%$ osmium tetroxide, dehydrated through a graded ethanol series and embedded in Epon, following transitional stages in ethanol. Thick sections were stained with $0.25 \%$ alkaline toluidine blue. Selected areas were trimmed and thin sections were stained with $2 \%$ uranyl acetate and lead citrate and examined using a Zeiss EM-109 transmission electron microscope.
Morphometric analysis was performed by observing hepatic and pontine HE stained sections from mice belonging to groups I and II. Three sections per mouse from the liver and 3 from the pons were scanned and the number of lesions per $\mathrm{mm}^{2}$ was obtained using Optimas imaging analysis program (Optimas Corporation of Edmonds, Washington, USA). Student's t-test was used to measure the significance of differences between group means.

This experimental study was approved by the Scientific and Ethics Commission of the Paulista University.

\section{RESULTS}

Hepatomegaly and splenomegaly were seen from the $15^{\text {th }}$ to the $75^{\text {th }}$ day post-inoculation in animals from group I (immunosuppressed mice), although in mice from group II (immunocompetent) only hepatomegaly was evident. All mice inoculated with E. cuniculi presented weight loss, but no mortality was recorded during the experimental period in both groups. Macroscopical lesions in the CNS were not found at necropsy. Microscopically, infected mice presented multifocal granulomas, predominantly in the liver, but also occurring in the spleen, kidneys, lungs, guts, cerebrum, cerebellum, brainstem (mesencephalon, pons and medulla oblongata) and spinal cord (cervical, thoracic and lumbar). Table shows the number of lesions per $\mathrm{mm}^{2}$ in the liver and pons from groups I and II. The proportion of such granulomas in both sites was higher in group I comparing to group II. A lymphocytic, diffuse, non-suppurative menigoencephalomyelitis was observed, with neuronal degeneration and necrosis, secundary demyelination, macrophagic infiltration and reactive astrocytosis. These granulomas appeared as nests of 20 to 40 pleomorphic cells, presenting acidophilic cytoplasm and central nuclei (Fig 1). E. cuniculi spores were seen in the microgranulomas or occurred unassociated with a tissue reaction throughout the neuropil. Increased astrocytic GFAP immunos-

\begin{tabular}{lcc} 
Table. Mean number of lesions in hepatic and pontine sections of mice from groups I and II. \\
\hline Group & $\begin{array}{c}\text { Mean number of lesions } \\
\text { in the hepatic tissue } / \mathrm{mm}^{2} \\
\text { (mean } \pm \text { s.e.m.) }\end{array}$ & $\begin{array}{c}\text { Mean number of lesions } \\
\text { in the pons } / \mathrm{mm}^{2} \\
\text { (mean } \pm \text { s.e.m.) }\end{array}$ \\
\hline $\mathrm{I}^{*}$ & $70.57 \pm 55.45^{\mathrm{a}}$ & $10.52 \pm 4.82^{\mathrm{a}}$ \\
$\mathrm{II}$ & $45.70 \pm 13.87$ & $3.36 \pm 4.73$ \\
\hline
\end{tabular}

${ }^{*}$ Group I immunosuppressed mice inoculated with E. cuniculi; group II immunocompetent mice inoculated with E. cuniculi. ${ }^{\mathrm{P}}<0.05$ for group I versus II as calculated by Student's t-test. 


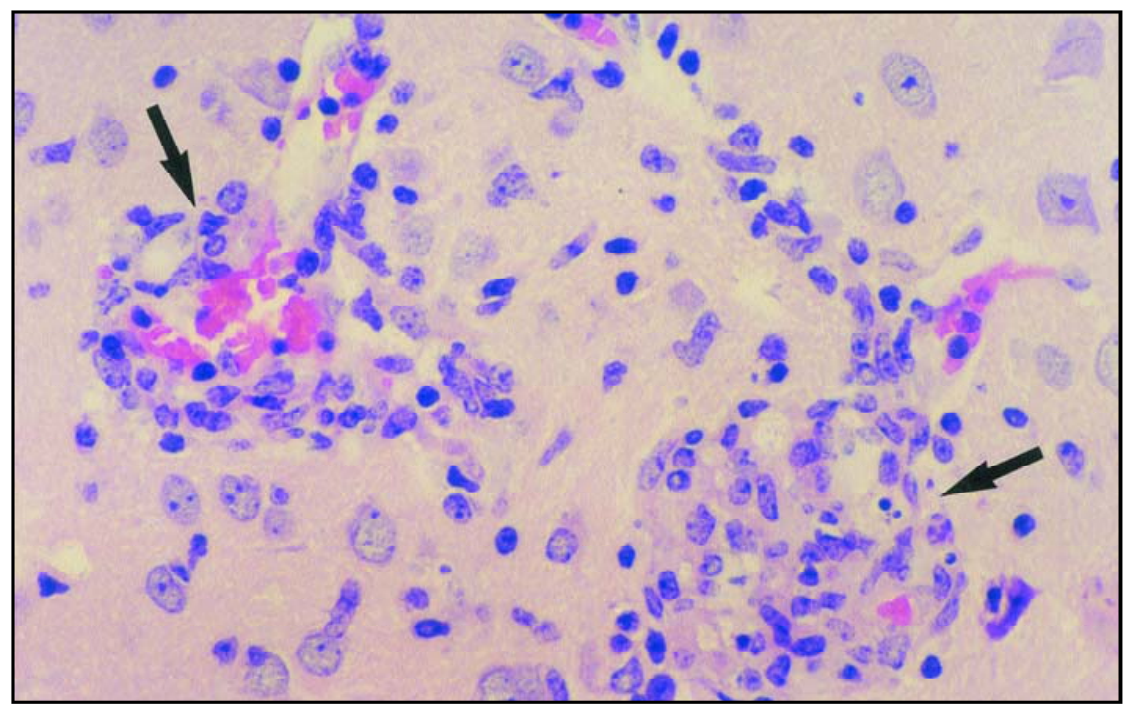

Fig 1. Microgranulomas (arrows) in the brainstem 75 days after $E$. cuniculi inoculation. $H-E$, Group I, 650x.

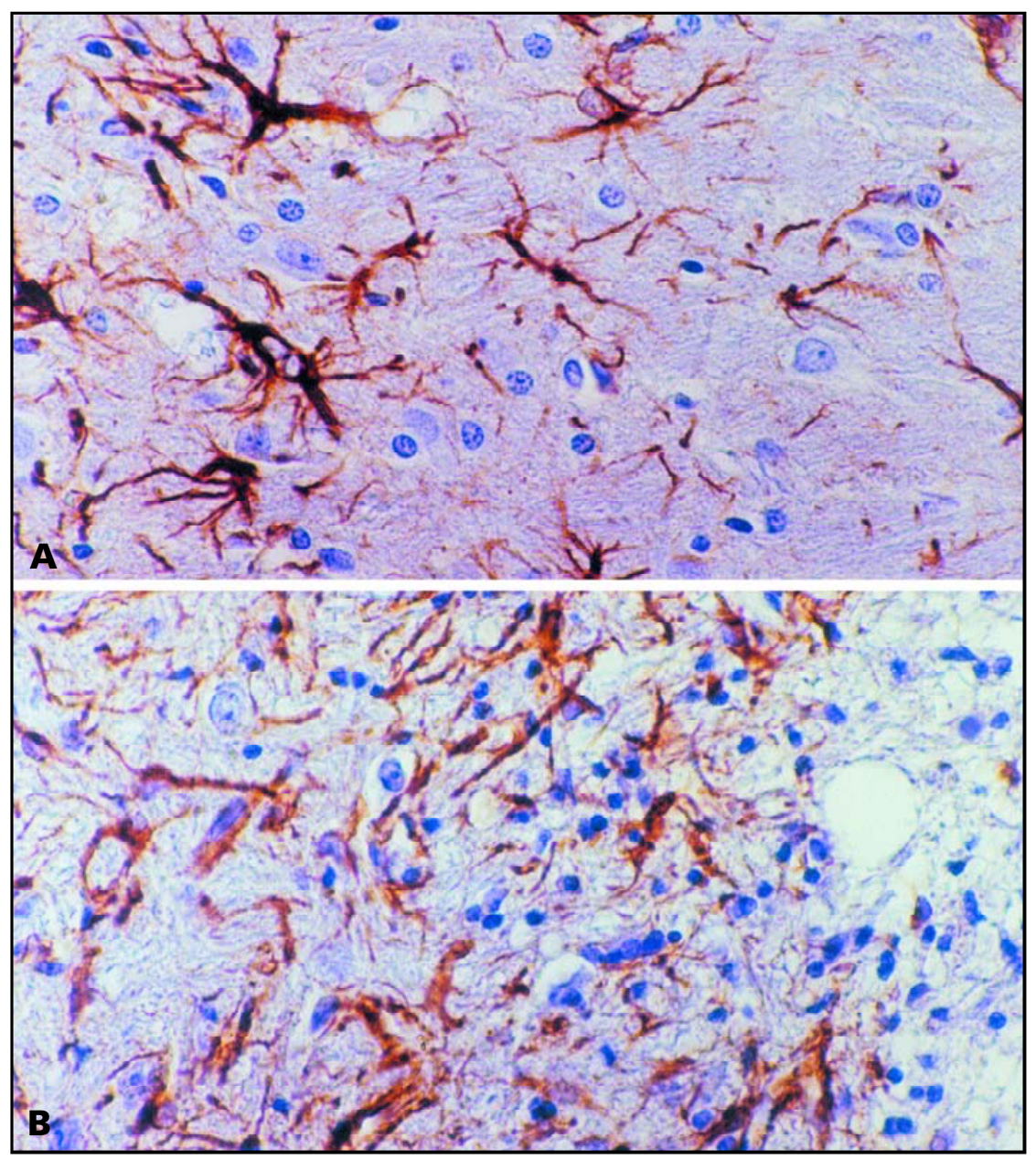

Fig 2. Reactive astrocytes showing increased Glial Fibrillary Acidic Protein immunostaining (A) and Vimentin reexpression (B) in mice from group I. A) GFAP, Electron micrograph, 650x; B) VIM, Electron micrograph, 650x. 


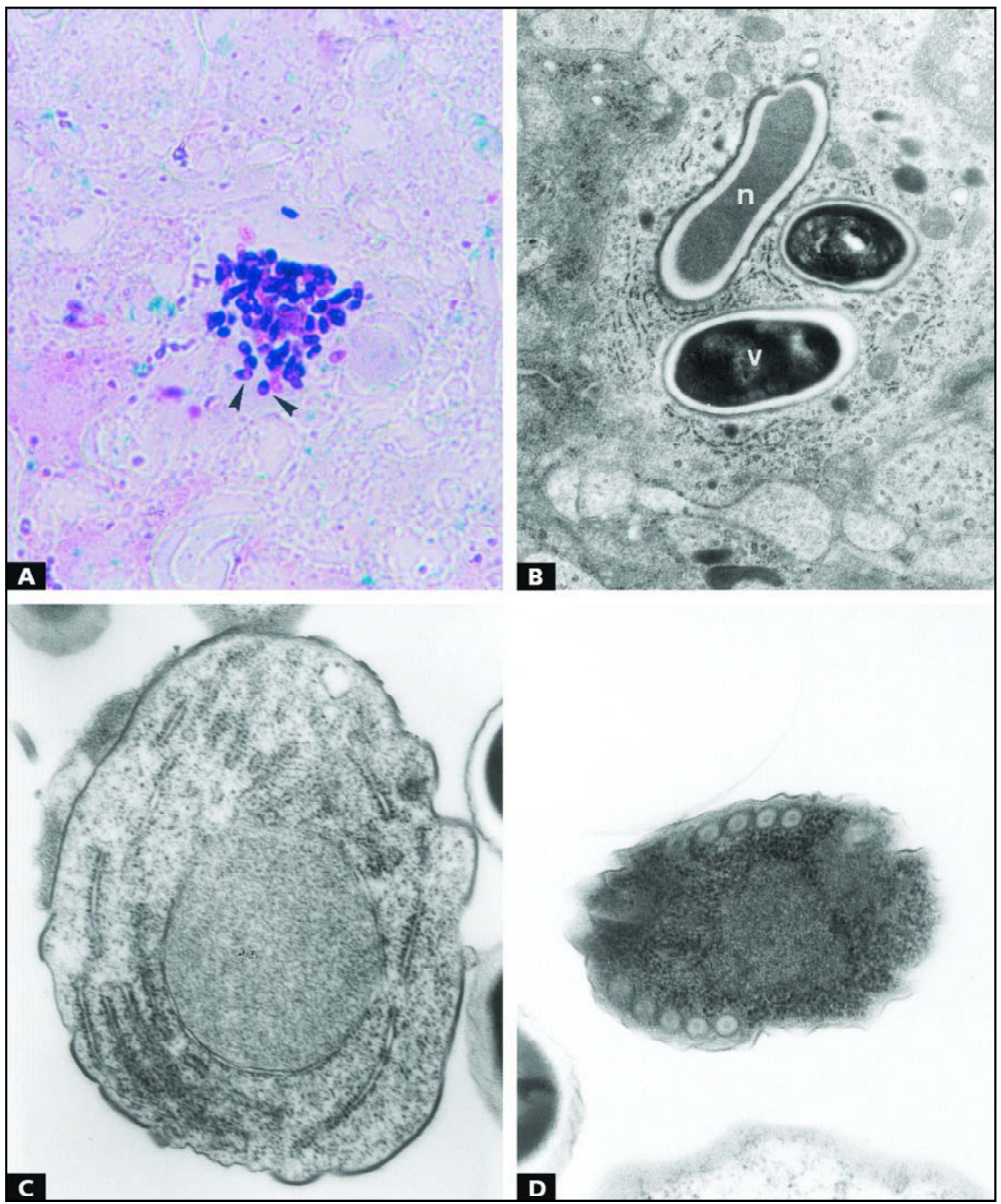

Fig 3. Proliferative forms and spores of E. cuniculi from mice immunosuppressed with CY. Group I. A) Spores. Note the equatorial belt-like stripes (arrowheads). Gram-Chromotrope, 650x; B) Viable (v) and non-viable (n) spores. Electron micrograph, 15.870x; C) Sporont. Electron micrograph, 75,000x; D) Sporoblast. Electron micrograph, 50,000x.

taining was noted (Fig 2A) and reexpression of Vimentin (Fig 2B) was found in reactive astrocytes surrounding the granulomas. The parasites were observed with difficulty in Hematoxylin-Eosin stained sections, but were easily identified using GramChromotrope technique as ovoid strutures (Fig $3 \mathrm{~A})$ measuring from 2.4 to $3.2 \times 1.7$ micrometres and presenting a prominent equatorial belt-like stripe. Some proliferative forms (meronts, sporonts, sporoblasts) and spores were found in parasitophorous vacuoles within neural cells and macrophages (Fig 3B). Mature spores were usually so dense that internal organellae were difficult to observe although a coiled filament (polar tubule) and sometimes a single nucleus were seen. The polar tubule was arranged into 5 or 6 coils in the pos- 
terior region of the spore. The wall of the mature spore was thickened. The spores were surrounded by a thin, electron-dense exospore that appeared to be slightly wrinkled; a thick electron-lucent endospore; and a thin cell membrane that encased the spore contents. Spores with extruded polar tubules were not noted. Meronts were seen as unicellular structures, irregularly round, with one single nucleus, numerous free ribosomes and endoplasmic reticulum cisternae dispersed in the cytoplasm. They were delimited by a plasma membrane and adhered to the parasitophorous vacuole membrane. Meronts with 2 nuclei and cytoplasmic prolongaments in a characteristic pattern of binary fission were also seen. Sporonts were very similar to meronts, but they showed a thicker and a more electron-dense and ruffled membrane (Fig 3C). Sporoblasts presented a single nucleus, a double-membrane wall, the most external being covered by an electron-dense material (Fig 3D). Their cytoplasm contained many free ribosomes uniformly distributed within the cell and a rudimentary coiled filament was already seen.

Some degenerating spores within the cytoplasm of macrophages retained an intact wall, which was depicted as a narrow, corrugated shell (exospore) circumscribing a discrete electron-lucent halo (endospore). The distinctly preserved spore wall usually surrounded a central, homogeneous mass of destroyed organelles. This clear space appears to coincide with the electron-lucent space described above for the mature viable spore. No recognizable organelles, including the cytoplasmic membrane, remained in non-viable spores, all having been digested to a moderately electron-dense homogeneous mass.

\section{DISCUSSION}

Encephalitozoonosis falls into 2 basic pattern $s^{4,10}$. The first form appears as an acute and clinically detectable disease, frequently resulting in death. It is easily produced in neonates as well as in immunologically compromised animals ${ }^{4-7,10,11}$. On the other hand, the second pattern appears as a chronic and silent infection ${ }^{4,12}$. Possible mechanisms of persistence of infection may include the sugestion that such protozoans block the fusion of lysosomes to the parasitophorous vacuoles or the supposition that parasites can evade from immune defenses of the host ${ }^{13,14}$. Much of what is known about mammalian microscoporidioses has been understood from experimental models, which provide useful ap- poaches for the study of humans infected with these protozoans ${ }^{15}$. Human and experimental animal microsporidiosis are both characterized by wide dissemination of the organisms, necrosis of infected cells, presence of lymphocytic inflammatory infiltrates and parasites, free in tissues or in intracellular parasitophorous vacuoles ${ }^{16}$.

Microsporidia are ubiquitous and occur worldwide as obligate intracellular protozoans in most $\mathrm{ma-}$ jor groups of the animal kingdom ${ }^{1}$. Interest in the microsporidia is growing as these organisms are recognized in immunocompromised patients or immunosuppressed recipients of organ transplants $\mathrm{s}^{5-8}$, as well as in normal individuals, including children and travelers ${ }^{17}$. Furthermore, concern exists about the potential of zoonotic and waterborne transmission of microsporidia to humans ${ }^{1,17}$.

Our observations show that $E$. cuniculi behave in a manner similar to other parasites such as Toxoplasma gondii ${ }^{14}$. Parasites were capable of infecting and residing within macrophages. E. cuniculi spores with intact walls were found inside parasitophorous vacuoles, revealing that spores were phagocytosed despite the fact that the animals were submitted to an immunosuppressive treatment with CY. Some spores were observed without any sign of internal damage suggesting that they were able to survive in a compartment which failed to fuse with lysosomes. Both merogony and sporogony were found in infected macrophages, thus indicating that parasites were able to complete their life cycle. Few endocytosed parasites presented morphological evidences of intracellular hydrolisis such as wall irregularities and cytoplasmic electron-luscence, and phagosome-lysosome fusion was occasionally seen. As CY treatment interferes with immune activation of phagocytic cells, it can be assumed that macrophages from immunosuppressed mice failed to kill the protozoans and could serve as a vehicule for parasite propagation in the host. It remains obscure if $E$. cuniculi enter macrophages by phagocytosis or by injecting the sporoplasm into the host cell cytoplasm through an extruded polar filament ${ }^{18,19}$.

Prominent astrocytic reaction was noted around the granulomas and it was characterized by increased Glial Fibrillary Acidic Protein immunoreactivity and reexpression of Vimentin. GFAP and VIM are the most important components of the astrocytic intermediate filaments ${ }^{20,21}$. It is known that soon after birth, there is a progressive disappearance of VIM and its replacement by GFAP, although 
astrocytes may recover their capacity of expressing VIM after injury in adult animals ${ }^{20,21}$.

Previous investigations showed that immunosuppression in mice with $100 \mathrm{mg} / \mathrm{kg}$ of CY, twice a week by intraperitoneal route, produced an acute form of encephalitozoonosis, recognized as a disseminated and lethal infection ${ }^{22}$. It is important to emphasize that with the immunosuppressive schedule used in our study ( $50 \mathrm{mg} / \mathrm{kg}$, twice a week, intraperitoneal route), the chronic form of the disease was achieved.

One relevant reason to study animal diseases is that they may help us to identify or antecipate diseases in humans ${ }^{15}$. Microsporidiosis is a good example of the sucess of this strategy. Although microsporidial infection has been recognized in animals for about 80 years, almost nothing was known about the natural history of microsporidial disease in the human population before the occurrence of acquired immunodeficiency syndrome (AIDS) ${ }^{17}$. In this context, experimental animal models have provided the fundaments from which undestanding of disease pathogenesis, diagnostic techniques and therapeutical approaches for human microsporidiosis have appeared.

Acknowledgement - The authors wish to thank Dr. Wafaa S. Hollister (Department of Biology, Imperial College of Science, Technology \& Medicine, London) for supplying the strain of $E$. cuniculi used in this investigation.

\section{REFERENCES}

1. Didier ES, Snowden KF, Shadduck JA. Biology of micosporidian species infecting mammals. Adv Parasitol 1998;40:283-320.

2. Wasson K, Peper RL. Mammalian microsporidiosis. Vet Pathol 2000;37:113-118

3. Didier ES, Didier PJ, Snowden KF, Shadduck JA. Microsporidiosis in mammals. Microbes Infect 2000;2:709-720.
4. Gannon J. The course of infection of Encephalitozoon cuniculi in immunodeficient and immunocompetent mice. Lab Anim 1980;14:189-192.

5. Didier ES, Varner PW, Didier PJ, et al. Experimental microsporidiosis in immunocompetent and immunodeficient mice and monkeys. Folia Parasitol 1994;41:1-11.

6. Bryan RT. Microsporidiosis as an AIDS-related opportunistic infection. Clin Infect Dis 1995;21:62-65.

7. Sulaiman IM, Matos O, Lobos ML, Xiao L. Identification of new microsporidian parasite related to Vittaforma cornea in HIV-positive and HIV-negative patients from Portugal. J Eukaryot Microbiol 2003;50 Suppl:S586-S590.

8. Didier ES, Didier PJ, Friedberg DN. Isolation and characterization of a new microsporidian, Encephalitozoon hellen (n. sp.), from three AIDS patient with keratoconjunctivitis. J Infect Dis 1991;163:617-621.

9. Moura H, Silva JLN, Sodré FC, et al. Gram-Chromotrope: a new technique that enhances detection of microsporidial spores in clinical samples. J Eukaryot Microbiol 1996;43:94-95.

10. Koudela B, Vitovec J, Kucerova Z, Ditrich O, Tranicek J. The severe combined immunodeficient mouse as a model for Encephalitozoon cuniculi microsporidiosis. Folia Parasitol 1994;40:279-286.

11. Thomas C, Finn M, Twigg L, Deplazes P, Thompson RCA. Microsporidia (Encephalitozoon cuniculi) in wild rabbits in Australia. Aust Vet J 1997;75:808-810.

12. Schmidt EC, Shadduck JA. Murine encephalitozoonosis model for studying the host-parasite relationship of chronic infection. Infect Immun 1983;40:936-942.

13. Liu JJ, Greeley EH, Shadduck JA. Mechanisms of resistance/susceptibility to murine encephalitozoonosis. Parasite Immunol 1989;11:241-256.

14. Jones TC, Hirsch JG. The interaction between Toxoplasma gondii and mammalian cells: II. The absence of lysossomal fusion with phagocytic vacuoles containing living parasites. J Exper Med 1072;136:1173-1194.

15. Snowden KF, Didier ES, Orenstein JM, Shadduck JA. Animal models of human microsporidial infections. Lab Anim Sci 1998;48:589-595.

16. Van Dellen AF, Stewart CG, Botha WS. Studies of encephalitozoonosis in vervet monkeys (Cercopithecus gerythrus) orally inoculated with spores of Encephalitozoon cuniculi isolated from dogs (Canis familiaris). Onderstepoort J Vet 1989;56:1-22.

17. Weiss LM. Microsporidia 2003: IWOP-8. J Eukaryot Microbiol 2003;50(Suppl):S566-S568.

18. Couzinet S, Cejas E, Schittny J, Deplazes P, Weber R, Zimmerli S Phagocytic uptake of Encephalitozoon cuniculi by nonprofessional phagocytes. Infect Immun 2000;68:6939-6945.

19. Van Dellen AF, Botha WS, Boomker J, Warnes WEJ. Light and electron microscopical studies on canine encephalitozoonosis: cerebral vasculitis. Onderstepoort J Vet 1978;45:165-186.

20. Pixley SK, de Vellis J. Transition between radial glia and mature astrocytes sztudied with a monoclonal antibody to vimentn. Dev Brain Res 1984;15:201-209.

21. Takamiya Y, Kohsaka S, Toya S, Otani M, Tsukuda Y. Immuno-histochemical studies on the proliferation of reactive astrocytes and the expression of cytoskeletal ptoteins following brain injury. Dev Brain Res 1988;38:201-210.

22. Castro JM, Lallo MA, Spadacci-Morena DD, Bondan EF, Hirschfeld MMP Behaviour of Encephalitozoon cuniculi within macrophages from immunosuppressed mice. Acta Microscopica 1999;8:445-446. 